\title{
The Politics of Teaching, Funding and Publication in South African Anthropology: "Our Experiences"
}

\author{
D.L. Bogopa* \& T.S. Petrus*
}

\begin{abstract}
This paper takes a critical look at the politics of teaching, funding and publication that seemingly dominate the academic context of anthropology in South Africa. The views that will be expressed are of an inherently personal nature as they will reflect the experiences that we have had as young academics in our institution and beyond. There are numerous challenges that we have had to face; many of them having to do with the political context of teaching, funding and research/ publication. In this paper, we will indicate some of the major challenges that we have had to face, specifically within the context of teaching, funding and research. These three areas are of specific importance to us because, as young researchers/academics, these issues are critical in relation to our institution's criteria for academic staff development. However, despite the importance of these criterion, we will show, based on our own experiences, how institutional politics within the university context as well as the politics associated with publication, have become obstacles preventing us from developing successfully ourselves and making a meaningful contribution to the development of South African anthropology.
\end{abstract}

\section{Résumé}

Cet article jette un regard critique sur les politiques de l'enseignement, de financement et de publication qui dominent le contexte académique de l'Anthropologie en Afrique du Sud. Les points de vues explicités ici sont des expériences personnels que nous avons vécus dans notre

* Sociology and Anthropology, Nelson Mandela Metropolitan University. Email: David.Bogopa@nmmu.ac.za.

** Sociology and Anthropology, Nelson Mandela Metropolitan University. Email: Theodore.Petrus@nmmu.ac.za. 
institution et même au-delà entant que jeune académicien ou universitaire. Il ya plusieurs défis que nous avions eu à faire face, un bon nombre était en relation avec le contexte politique de l'enseignement, de financement, de recherche/publication. Dans cet article, nous allons présenter quels sont ces défis, particulièrement dans le contexte de l'enseignement, du financement et de la recherche. En tant que jeunes chercheurs/académiciens, ces trois domaines sont spécifiquement importants par rapport au critère de sélection qu'utilisent les personnels chargés de développement de notre institution universitaire. Cependant, malgré l'importance de ces critères nous allons montrer à partir de notre expérience personnelle comment les politiques institutionnelles dans le contexte universitaire, aussi bien que les politiques de publication, sont devenues des obstacles qui empêchent notre épanouissement et le développement de l'Anthropologie en Afrique du sud.

\section{Introduction}

As young academics, writing a paper of this nature is not entirely without risk. Within the academic arena, attempting to provide a critical look at the political context in which academic activities take place is sure to entail, as one of its consequences, stepping on the toes of established academics. However, despite the perceived risks involved in writing this paper, the authors, as young academics, recognise the need for writing a paper it. Vawda has stated, in the South African context, that '... anthropologists have generally left unquestioned anthropology's institutional existence...' (Vawda, 1998). It is with this view in mind that we recognise the need for writing a paper such as this. We depart from the assumption that there are others perhaps who have made similar observations to those that we will indicate in this paper. Our intention is not to be construed as an attack on our established colleagues, but should rather be viewed as a critical assessment of what we believe the key obstacles are that hinder the development of young academics. We have chosen to look specifically at the academic context of anthropology as we consider ourselves first and foremost as anthropologists, and that each of us is currently pursuing a doctorate in anthropology.

In the South African tertiary education context, widespread changes have occurred in recent years that have directly impacted the three key aspects of academic work, namely teaching, funding and publication. For many universities and technikons, the merging of tertiary institutions has provided the most significant challenges to academia. Due to the pressures exerted on universities by the South African government's Department of Education, many institutions are struggling to cope with the new demands and standards that have been placed on them. For the most part, these changes have been related to a political process, one that 
has infiltrated even the key activities of academia, namely teaching, funding and publication.

Over the last two decades if not more, the influence of politics has perhaps been more significant on anthropology in South Africa than on any other social science discipline. This is well illustrated by scholars such as Coertze (1999) and Sharp (2000). The apartheid context in South Africa since the late 1940s had created a polarisation of English and Afrikaans anthropologists. This political division was instrumental in the creation of a division in the discipline itself where a distinction was drawn between the practice of volkekunde and social anthropology. The former was criticised by English anthropologists as being used to support apartheid policies and ideology. As Sharp (2000) himself admits, '...it...is true that the two disciplines drifted apart as the system of apartheid became entrenched' (Sharp, 2000). So severe was this political division within South African anthropology that it resulted in the creation of two separate anthropology organisations, namely the Association for Anthropology in South Africa, which represented the English anthropologists, and the South African Society of Cultural Anthropologists, which represented the Afrikaans anthropologists (Sharp, 2000: 30; Bogopa, 2001: 216). It was not until 9 April 2001 that the two associations finally merged into one and became known as Anthropology Southern Africa (Bogopa, 2001). Despite this positive step, however, political differences may well still exist, even in the new association, as will be illustrated in this paper. In the new association, the new political challenge that needs to be overcome is transformation.

Our purpose in this paper is to provide a critical look at how politics has impacted on teaching, funding and publication. In this context, we view politics in the light of the institutional practice of anthropology which Vawda (1998) described as '... a mirror of the structures of power...' (Vawda, 1998: 28). We will specifically look at how politics impacts on the ability of young academics to perform these key tasks effectively enough to facilitate their development. Much of what we will discuss will be based on our personal experiences up to now as young academics. We will refer specifically to critical issues in the politics of teaching, funding and publication as these pertain to the discipline of anthropology.

\section{The Politics of Teaching Anthropology in South Africa}

There can be little doubt that in South African universities where anthropology is offered as a teaching subject, there are differences in terms of the contexts in which anthropology is taught. In some universities, such as the University of Cape Town (UCT), anthropology is regarded as 
a well established discipline and is taught as a discipline in its own right. In other universities, such as Nelson Mandela Metropolitan University (NMMU) where we are based, anthropology is nothing more than a subject group. This means that students can select certain modules or courses in anthropology and are not obliged to take all anthropology modules if it is not a major subject. Furthermore, at the NMMU, anthropology does not exist as a department on its own, but is based in the Department of Sociology and Anthropology, which also incorporates the History subject group. An additional factor is that there are only three staff members who teach anthropology at undergraduate and postgraduate level. These three staff members consist of one associate professor and two lecturers, both of whom hold a Masters degree in anthropology.

Since there are discrepancies across different universities in the teaching context of anthropology, there has emerged a sense that certain more established anthropology departments assume an air of superiority over those departments where anthropology is not well established. We have experienced something of this nature firsthand with one of our former anthropology graduate students who left NMMU at the end of his third year to pursue an Honours qualification in anthropology at another institution in South Africa. While studying at this institution, the student found it difficult to make any significant progress. Eventually, the situation became so bad that he decided to return to NMMU to continue his studies. The interesting thing is that while the student was a good performer at NMMU throughout his undergraduate studies, he was regarded as an under-performer at this new institution. As a postgraduate student, this created the impression that the undergraduate training that he had received at NMMU was not regarded as being at an acceptable standard for him to be able to successfully complete his studies at this new institution. The implication is that this student was at a disadvantage because he had received his undergraduate training at NMMU which was regarded as inferior. This experience illustrates that there are certain anthropology departments that maintain an attitude of superiority over others.

At NMMU, a second problem which we have encountered in the teaching of anthropology, a problem that is threatening to worsen in the near future, is the apparent sidelining of anthropology as a discipline of value. The NMMU Department of Sociology and Anthropology is located in the School of Governmental and Social Sciences, which is one of three Schools in the Faculty of Arts. Following the merger process, the university has embarked on a wide scale plan of academic restructuring which has translated into the physical moving of subject groups and departments 
to different campuses of the university. From our point of view there is a growing sense that the social science disciplines, including anthropology, that are currently being taught at NMMU, are gradually being sidelined through plans to have these disciplines relocated to one of the peripheral campuses of the institution. A relocation of this nature would have very significant implications for teaching anthropology at the university. It is speculated that there will be a significant decline in numbers of students who would enrol for anthropology courses as they would, for practical and financial reasons, not be willing to travel between campuses. A decrease in student numbers would mean a decrease in FTEs and this would ultimately have a negative impact on the viability of our anthropology modules. Thus, it becomes clear that the future of teaching anthropology at the university is under threat as a direct consequence of relocation.

The decision to relocate certain departments is not made by the university alone but is, to a large extent, a response to external pressure from the South African government. Within the context of the skills crisis in the country, particularly those skills associated with science, business and technology, there has been a drive from governmental level to make these areas focal points at tertiary institutions. This is one reason why at NMMU, there is an impression that the main campuses of the institution will house academic programmes and courses related to science, business and technology while the rest would be relocated to peripheral campuses. This situation shows that the teaching of anthropology is not free of a political context which, as far as we are concerned, will have negative implications on our ability to teach anthropology.

In light of these issues, in order to try to survive, we have attempted to improve our research activities as research outputs are also regarded as criterion for viability. However, being able to produce the much needed research outputs depends on funding. In the following section we will show that access to funding presents its own set of challenges and obstacles which, we believe, are also part of a political context that hampers young academics from developing their research capacity.

\section{The Politics of Funding}

There is a famous slogan within the academic circles in South Africa that says "You either publish or perish". Academics in South Africa are being constantly reminded, if not threatened, to publish or perish. An academic is expected to attend at least one local conference and one international conference per year and funding to attend these conferences is 
usually on condition that the papers presented at such conferences will, at a later stage, be sent for publication. The whole idea of encouraging academics to write research papers is to create an opportunity for third stream income, largely because the institution will benefit financially if a paper is published in an accredited journal. In South Africa, universities are subsidised by the Department of Education for articles and papers that are published in accredited or subsidised journals. For this reason, academics are encouraged to publish in accredited journals regularly. Although universities receive subsidies for these articles, academic authors receive a portion of the total amount, while the universities receive the major share of the funding.

The strategy of creating a third stream income is a positive initiative in the right direction because it encourages academics, particularly young academics, to become actively involved in writing articles for accredited publication. There are various advantages that this has for young academics, such as creating an opportunity for them to build up a research output record that could open up various opportunities for them to grow and develop. However, some academics, particularly young academics, find themselves frustrated because of a lack of support from the funding committees both within and outside of their institutions. For example, in some cases, young academics have difficulty in accessing funding because, with some funding committees, the criteria used for awarding funding carry conditions, such as that one must have at least published an article before one can be considered for funding. Inexperienced researchers or academics who have the potential to become good researchers get discouraged because, if one has not published yet, the chances are slim that one will be considered for funding.

Further, as academics, we are expected to publish articles in journals, yet the journal policies are not always taken into consideration. For example, some journals, particularly peer reviewed journals, publish only two issues per year and one may have to wait for up to six months to hear the outcome of a paper that one has submitted for review, largely because manuscripts are being sent to reviewers and it takes time to get feedback. Sometimes, journals do not even acknowledge that they have received an article to be considered for publication. We have both sent papers to different journals before and, in several cases, we never received any communication from editors.

According to De Jong (2002: 3) anthropologists in South Africa do not have serious problems in accessing funding. Subsidised funding and access to funding from the universities in South Africa are fairly readily obtained. The majority of anthropologists have previously accessed fund- 
ing through institutions such as the National Research Foundation (NRF), the Medical Research Council, Non-Government Organizations and the private sector. Furthermore, there is access to funding from US AID, the World Bank and other international institutions.

In light of the above-mentioned argument that funding is readily obtainable, our previous experience in terms of access to funding is slightly different. Over the past few years that we have been involved in applying for funding to these and other institutions, we have had great difficulty in being successful in our applications. Perhaps the funding institutions are inclined to fund already experienced researchers because, in our experience as young academics, it is difficult to obtain funding. One of us has previously applied twice for funding to the Medical Research Council. The other has applied more than once, unsuccessfully, to the NRF for funding for his doctoral studies. It is our argument that while De Jong (2002) suggests that access to funding is readily available, this access is politically controlled and hampers particularly young academics from obtaining funding. We have found that there have been inconsistencies in the feedback reports that we have received following the outcome of our applications. In some cases, based on the feedback we have received, our applications have been unsuccessful because certain details have been omitted from the application. However, since many of these applications have to be completed electronically, there is an application template that must be used to complete the application. On the template are all the relevant sections that are deemed necessary for the applicant to address. It is not possible to submit an application that does not have all the required sections completed. Thus, once the application is sent successfully to the funding institution it is assumed that all the information has been included. When one receives a feedback stating that not all the details have been included, it does raise certain questions. Often the feedback is also so sketchy that the questions remain unanswered, making it difficult for one to know how to go about reviewing and amending the application.

There is also the possibility that funding applications are rejected because the funders or those responsible for reviewing applications may not regard a particular research topic worthy of being funded. This could be partly explained in view of the issue referred to earlier concerning the national drive towards focusing on scholars of science, business and technology. However, it is also possible that even within the field of social sciences, some academics who serve on funding committees may have a limited view of what topics could potentially be regarded as wor- 
thy of funding. There may be an academic bias towards funding certain proposed topics but not others. This implies that regardless of how well one is able to motivate why one has chosen a particular research topic, if the funding committee does not regard that topic as significant enough to fund, the proposal will be rejected.

Furthermore, the problem of funding is not only unique to South African anthropologists, in Kenya, anthropologists have also experienced problems of funding and the teaching of anthropology has been restricted. Research activities involving anthropologists in Kenya has been severely disrupted by autocratic political interventions. There is a tendency to undermine academic research excellence. There is no academic freedom; academics are often labelled as "anti-government", particularly when they are critical with some of the government policies (Kareithi, 1998: 46-47).

\section{Collaborative Research}

One way perhaps to combat the above-mentioned obstacle regarding funding is to encourage young anthropologists to become involved in collaborative research. It is very important that anthropology departments work together, particularly on research topics or projects where there is common interest. The whole idea of working together is to share some research experiences and ideas with the view of building research capacity particularly among inexperienced researchers.

There are four anthropology departments in universities in the Eastern Cape province in South Africa, where we are based, yet there is hardly any collaborative research that is being done. These four anthropology departments are geographically situated within each other's reach, but there is no collaborative research work conducted unless it is done by individual academics without the knowledge of their colleagues. There are also no seminars organized so that members and students of these anthropology departments can share ideas.

In some cases, a lack of collaboration may not only be due to a lack of interest between anthropology departments, but it could also be the result of politics and the unequal distribution of resources to facilitate collaboration. An example of this had previously existed in two former Durban based anthropology departments. A research project on informal settlement was started that could have benefited greatly from collaboration between the two departments. However, instead of involving both departments in the project, it was eventually given to the department that was better established in terms of resources. Even though the excluded department had research experience in the field of informal 
settlements and had a significant contribution to make to the project, it was given to the anthropology department based at the historically white university which was better equipped (Vawda, 1998: 17). This example shows that politics can hamper collaboration between anthropology departments, especially if these departments are evaluated in terms of being either historically black or white, or as either having or not having the required resources.

However, on a positive note, we have previously worked on a conference paper entitled "Natural and Supernatural: Intersections between the spiritual and natural worlds in African witchcraft and healing: The case of Southern Africa". We presented the paper at an international conference and we later submitted the paper for publication where it was accepted and published in 2007 in the Indo-Pacific Journal of Phenomenology. The paper was the first collaborative effort by two colleagues from the same department.

Furthermore, the issue of housing in South Africa presents one of the most significant areas where collaborative research can be encouraged. As housing remains one of the most fundamental problems in South Africa, anthropologists have been involved in conducting collaborative research with a view to unpacking some of the key issues in the housing sector. A collaborative research project involving an anthropologist with two urban academics was conducted in Cape Town with a view to contributing to the local debate on housing policy in South Africa (Spiegel, 55-56).

In line with the spirit of collaborative research, we are both currently involved in a study entitled "Desegregation and racial categorisations: A comparison between France and South Africa". This is a collaborative research project involving colleagues in South Africa and France.

\section{The Politics of Publication}

Within the context of South African anthropology and particularly with reference to publication, we have discovered that it is very difficult to publish in Anthropology Southern Africa, the anthropology journal formerly known as the South African Journal of Ethnology.

A statistical analysis of published articles in the former South African Journal of Ethnology from 1992 until 1998 shows that there were barriers unconsciously or consciously created in terms of publication. A total number of 140 articles were published and 86 of these articles were written by anthropologists. The statistical breakdown revealed the following: 61 published articles were written by white Afrikaans-speaking 
males, 14 published articles were written by Afrikaans-speaking females, 6 published articles were written by Non-Afrikaans-speaking males, 3 published articles were written by two black males, 1 article by a German speaking female, 1 article by an English speaking female and no articles were published by black females (Jansen Van Rensburg \& Van Der Waal, 1999: 49).

The above-mentioned statistical analysis clearly shows that it was difficult to publish in the former South African Journal of Ethnology. Despite the change of name, it is still difficult to publish in the current Anthropology Southern Africa Journal. Informal discussions with two black female anthropologists based in South Africa provided us with some information that there are people who share the same frustration with us. Both female anthropologists had previously sent their papers to Anthropology Southern Africa to be considered for publication, but their papers were rejected.

We have experienced similar frustrations with the journal. We have both previously sent research papers to be considered for publication. The first paper in question was entitled "A Critique of Traditional Courts, Community Courts and Conflict Management". The response from the Anthropology Southern Africa journal editor was that the article did not meet the required standards and that the manuscript was not based on credible research other than a measure of participant observation. There were no constructive comments from the reviewers to help improve the above-mentioned paper. The same paper was then later submitted to a journal of criminological studies, known as Acta Criminologica, where it was accepted and published without any hassle.

One of us also submitted his own paper in 2004. This paper was entitled "Engaging the Supernatural: Anthropology and the Limitations of Scientific Rationalism". As in the above-mentioned case, the paper was rejected, but without the provision of any helpful comments from the editor and reviewers. Although comments were given, these implied that the central idea of the paper had to be drastically changed, presumably because it did not fit in with the more conventional epistemological views of the reviewers. It appears that a monopoly exists on what constitutes valid ideas that are worth publishing in the journal. Any challenges to the more conventional ideas in the discipline are not favourably received by those who have the power to decide whether a paper is published or not. Preventing the publication of ideas that challenge the conventional is not only harmful to the confidence building of young authors, but is also detrimental to the development of the discipline. 
Booyens (2000) has argued that the social sciences, including anthropology, are at a crossroads due to the increasing influence of radical interpretive approaches that challenge conventional thought (Booyens, 2000: 111). It can therefore be argued that senior academics can no longer claim that their perhaps outdated ideas are still the dominant ideas in the discipline. These ideas are being challenged and these challenges have to be acknowledged. The only way this can be done is to allow non-conventional ideas to be published. This is how a discipline develops and grows. If alternative views are prevented from being published there is a risk that South African anthropology will become stagnant and useless.

In 2005, at a meeting of Anthropology Southern Africa, which is the only major anthropology association in South Africa and which is the home of the journal, we raised the question of publications in the journal. Needless to say our criticism was not well received.

Another important issue in publishing in Anthropology Southern Africa is the fact that senior anthropologists who serve on editorial and review committees of the journal monopolise the journal for their own publications. There have been numerous issues of the journal where the same authors have published more than one article in the same edition in the same year. When we looked into this matter we found that they were also members of either the editorial board, the board of consulting editors or office bearers and members of the council of the association. In our view this presents an obstacle to young anthropologists who attempt to publish in the journal because they are being prevented by senior, more established authors who control access to publication in the journal.

One of the authors of this paper also wrote a joint paper in 2001 entitled "Challenges facing tertiary institutions in the new millennium: Mono and Multicultural Paradoxes and How to survive them". This paper was submitted to a journal known as the Perspectives in Education for publication. It was later rejected with some of the comments from the reviewers stating that there were a lot of sweeping statements in the paper and many sarcastic comments. The same paper was submitted to Ethnonet-Publication and it was published electronically in 2004 without problems.

Our anthropology colleagues based at other institutions also had similar experiences. One colleague sent a paper to Anthropology Southern Africa in 2004. The title of the paper was "Ghanaian entrepreneurship in South Africa". The paper was rejected and according to the author, the comments were disheartening and demoralising for a young researcher. The 
same paper was submitted for publication in New Zealand and it was accepted and published in the Handbook of Research on Ethnic Minority Entrepreneurship.

Another anthropology colleague wrote a paper entitled "The Secular basis of Traditional Leadership in KwaZulu-Natal". This paper was sent to Anthropology Southern Africa and was rejected. According to the author, the comments from reviewers were not constructive and helpful towards improving the paper. The author decided to send it to another journal and it was published in the Alternation journal - Special Edition No.2, 2005.

The above-mentioned examples clearly show how young anthropologists are finding it difficult to publish in a journal belonging to Anthropology. We have already made a decision that we will think twice about sending our work to the Anthropology Southern Africa journal largely because our papers are not considered for publication because of an impression that the journal is being reserved for the elite few. The fact that young anthropologists feel that they do not have a home in their own discipline's journal to publish is, in our view, cause for concern as it reflects the politics involved in the process of publication.

\section{Solutions and Recommendations}

The issue of transformation within the context of South African Anthropology was raised in 2005 in one of the publications of The African Anthropologist. It was stated that the process of transformation is moving very slowly and it needs to be fast-tracked. Black, as well as female anthropologists in South Africa need to be given a chance to serve on the Anthropology Southern Africa association's executive committee, as well as to publish in Anthropology Southern Africa so that they can be in a position to raise issues of concern (Bogopa, 2001: 221).

The policy of Anthropology Southern Africa needs to be re-visited, particularly with reference to authors who publish two or more papers in one journal issue and also authors who publish in two journal editions in succession. Others, particularly younger authors, must be given a chance to publish as well.

We are not suggesting that the Anthropology Southern Africa reviewers and editors should act as mentors to young anthropologists, but we are suggesting that at least constructive comments on submitted papers should be given so that young anthropologists can improve their papers. We firmly believe that there is no "unpublishable" paper. There is always room for one to improve on a paper if one is guided properly. 
The issue of "standard" as written in the Anthropology Southern Africa association's proposed constitution for the New Association needs to be clearly defined, largely because it is confusing (Anthropology Southern Africa Proposed Constitution for the New Association, 2001).

Furthermore, we suggest that Anthropology Southern Africa should organize workshops on how to publish in its journal because, as it stands now, most of the young anthropologists have no clue as to how the journal operates in terms of reviewing papers for publication.

With regard to funding, there is a great need for funding organizations such as Medical Research Council, National Research Foundation, Wennergren Foundation and others to review their evaluation procedures. With reference to Wennergren, we suggest that reviewers or the panel should be selected from the individual applicant's country, for example, reviewers from South Africa will be better equipped to evaluate applications from South Africa largely because they are familiar with the current issues and within the context of South Africa.

We acknowledge that these funding organizations are operating on tight budgets, but sometimes application forms with information from the applicant are not sufficient to convince the panel, hence there is a great need that applicants be invited to defend their applications/proposals.

\section{Reflections on Responses to Our Paper from the 2008 Anthropology Southern Africa Conference}

A summarised version of this paper was presented at the 2008 Anthropology Southern Africa (ASnA) conference held at the University of the Western Cape in Cape Town, South Africa, in September. We have included a section on the responses of conference delegates to our paper because we believe these responses to be directly relevant to the issues we have raised in the paper. The most significant responses came from senior colleagues and members of the Executive Council of the ASnA. Some of the responses were encouraging, in the sense that they reflected an acknowledgement of the injustices and marginalisation that are currently being committed within the association, and that we, as the young academics who had the courage to expose these issues, should continue to speak out against the lack of transformation in South and southern African anthropologies. Other responses to our paper have led to the need for further engagement and debate on several issues. Given what we consider to be the wide-ranging implications of the issues raised in the debate, we are currently engaged in a debate with senior colleagues 
and the international community of anthropologists, specifically those represented on the World Council of Anthropological Associations (WCAA).

There are several issues, as they relate to responses to our paper, that are of concern to us. Firstly, there is a perception that in South and southern Africa, there are superior and inferior anthropologies, which is reflected at both ideological and institutional level. In South Africa, this distinction is ideologically informed apparently as a result of the old division between British Social Anthropology and a form of ethnology called volkekunde. The history of this ideological distinction is complex but, as it relates to the issues raised in our paper, it is being used as a justification for the recognition of Social Anthropology as the superior type of anthropology, at the expense of volkekunde. The reason for this distinction is that volkekunde, in the South African context, was used as a means of supporting apartheid structures and ideologies, for this type of anthropology was associated with Afrikaans tertiary institutions. English universities, on the other hand, as the homes of English Social Anthropology, are viewed as superior because of their critique of Afrikaans universities' support of apartheid. Consequently, historically English universities are seen as being "better" than historically Afrikaans universities. For this reason, there is an institutional discrimination, and anthropology departments are themselves part of this. In the contemporary context, anthropology departments at English institutions appear to want to maintain the status quo as they are benefiting from the situation. This is how they continue to maintain their hegemonic practices within anthropologies of South Africa. This is a situation that cannot be allowed to continue unchallenged. The most obvious reason why this perception should be challenged is that English universities, and, for that matter, English anthropology departments in South Africa, were just as much supporters of apartheid as were the Afrikaans institutions that they so readily criticise. The University of Cape Town (UCT) posted an official apology to the late Prof. Archie Mafeje on the internet for its withdrawal of his appointment as Senior Lecturer in Social Anthropology at UCT in 1968 (see http://www.uct.ac.za/downloads/uct.ac.za/about/ management/vcinstallation/Mafeje_apology.pd). Also, Rhodes University extended a recent apology in an Eastern Cape newspaper for its role in supporting apartheid policies in the past (Daily Dispatch, 18 September 2008). Thus, even English universities have apartheid "skeletons in the closet" and have no basis to assume a moral superiority over Afrikaans institutions. 
The second issue that came as a response to our paper was the assertion that our papers that were not published in the ASnA journal were rejected because they were not "anthropological". As one senior colleague and Executive Member of ASnA added, he would need to evaluate our papers to determine whether they were anthropological or not. The question that we raise is this: what makes a paper anthropological? A second question that we raise is: how can an individual assume the authority to evaluate the anthropological value of a paper for publication in an anthropology journal? It is perhaps significant that the person who made this comment was an anthropologist from UCT. This seems to suggest once again the point made earlier that some anthropologists from English universities seem to think that they have the authority to make certain claims regarding the discipline as a whole, even to the extent of deciding which papers are eligible for publication in an academic journal and which are not. An analysis of the ASnA journal seems to reflect this very issue because it seems that preference is given to those South African authors who are based at English universities or who subscribe to the Social Anthropology school of thought. Thus, academics from other South African institutions or those who do not subscribe to the dominant school of thought are not favourably considered for publication in the journal. This is also an issue that should be challenged.

Thirdly and finally, the issue of standards was cited as a possible reason why some papers are rejected for publication in the ASnA journal. While we do accept that there must be standards in order to ensure the quality of academic publications, questions should be raised when it appears that the maintenance of standards is being used as an excuse to marginalise young academics from non-English universities or who do not subscribe to the Social Anthropology hegemony. Our experiences have revealed that the rejection of our papers from the ASnA journal had much less to do with maintaining standards but more with the monopoly of the journal for an elite few. Again, we have an obligation to challenge this kind of practice.

\section{Conclusion}

As indicated at the beginning of this paper, a fair amount of risk has gone into writing this paper, but at the same time, we do feel that there is a need for young academics in anthropology to express the frustrations and concerns that they feel are hampering them from realising their full potential. We do realise that regardless of what we or anyone else may do, politics is a reality that cannot be escaped. It will always be there. We 
are unequivocally reminded of this by the statement that '... anthropology is politics, whether anthropologists like it or not...' (Huizer and Mannheim, 1979: 10 quoted in Jansen van Rensburg, 1998: 55). However, as scholars that have been trained to be critical thinkers and to be the social conscience of our societies, speaking out against perceived injustices, whether academic, institutional or otherwise, is what we must do. We are the future of our discipline and, therefore, we need to do whatever it takes to create a situation that will be conducive to our development as academics. It will not be easy because change itself is not easy. As anthropologists, studying change in societies has always been a feature of our research. However, now we, ourselves, have to be the agents of change in our own institutions and organisations. Anthropologists are not immune to the complexities which change can create because we are, first and foremost, human beings, and as human beings we often find change difficult to accept. But, like politics, change too is something which we cannot escape. Though it may take a long time, we, as young anthropologists supported by some of our established colleagues, should continue to struggle to facilitate positive change in our respective institutions, departments and organisations. The only way to achieve this will be to actively challenge the politics of teaching, funding and publication, and in this way effect the necessary transformation that will take anthropology in South Africa and Africa to new heights.

Finally, as Minaar (2007: ii) indicated, researchers from the different disciplines need to put aside their petty ideological and personal differences, but refocus efforts in prioritizing research by creating collaborative research networks, secure funding and build centres of research excellence.

\section{Notes}

1. "In the new association, the new political challenge that needs to be overcome is transformation" (pg 2) - although there is no explanation given there as to what transformation actually means.

2. Anthropology Southern Africa is the name of a journal published by the regional association of the same name: Anthropology Southern Africa (ASnA).

3. Green has taken pains to critique assertions that associate indigenous knowledges with socio-political identity claims.

4. Indeed, one of those was Theodore Petrus (Pauw and Petrus 2003).

5. At its largest, right now and after the present editor extended it to ensure representation from as many South African universities as possible, the editorial board comprises 22 members, not all of whom have published in the journal in the past six years. 
6. In the same six-year period, another author has published 3.5 articles, yet another 3.3 articles, and yet another (a guest editor of a special issue) 3 articles (including a special issue introduction). The first of these three authors has also been on the editorial board for some years; the last only recently.

7. I have not here included two instances where a special issue guest editor's introduction and substantive article have both been published in that special issue.

8. The journal now has guidelines for its readers to use when assessing a submitted paper, and a template for commenting. It might be wise to publish those in the journal alongside the guidelines for contributors.

9. Becker (2007: 89) comments on the apparent proclivity in South Africa of some "budding anthropologists "at home" ... to reify essentialist popular views of culture(s) as bounded, timeless entities'. And she refers in that context to what she calls a cynical quip made by a colleague at ASnA's founding meeting in 2001 that we might be seeing in that a revival of "'volkekunde with a dollop of black consciousness"'.

10. The South African Department of Education policy of doling out publication subsidies to institutions which host authors who publish in a list of 'accredited journals', and universities' need to generate income from sources other than student fees and state subsidies for student registrations, is highly contentious. Space precludes a fuller discussion here.

11. At the time of writing these were the only recent issues that were available to me.

12. By black I mean the statutory classification of Indians, Coloureds and African as black.

13. It also raises pertinent issues of the relationship of anthropology to other social sciences and their contribution to knowledge in institutional ways such a journals. Such issues are important, though not directly relevant to my concerns here.

\section{Bibliography}

Anthropology Southern Africa Proposed Constitution for the New Association, 2001.

Bogopa, D., 2001, "Merging of the Two Associations of Anthropologists in South Africa", The African Anthropologist Vol. 8 (2), pp. 216-222.

Booyens, J.H., 2000, "Social Sciences at the Crossroads?", South African Journal of Ethnology, Vol. 23 (2/3), pp. 111-115.

Coertze, R.D., 1999, "Kommentaar op Geignoreerde Kritiek", South African Journal of Ethnology Vol. 22 (3), pp. 81-96.

Daily Dispatch, 18 September, 2008. Rhodes apologises for pre-1994 wrongs.

De Jong, M., 2002, "Deconstruct, Self-destruct or Reconstruct: The State of Anthropology in Southern Africa", Anthropology Southern Africa 25 (1\&2), pp. 1-6. 
Huizer, G., and Mannheim, B., (eds). 1979, The Politics of Anthropology: From Colonialism and Sexism Toward a View From Below, The Hague: Mouton.

Jansen van Rensburg, F., 1998, “Power, Privilege, Suffering and Existentialism: The Exclusion of Anthropologists in the Era of Political Correctness", African Anthropology Vol. V (1), pp. 55-80.

Kareithi, J.N., 1998, "Facing up the Development Agenda: is Anthropology in the Core or Periphery?", African Anthropology Vol. V (1), pp. 33-54.

Jansen Van Rensburg, F. \& Van Der Waal, K 1999, "Continuity and Change in South African Cultural Anthropology (Volkekunde): Issues of Essentialism and Complexity", South African Journal of Ethnology, Vol. 22 (2).

Minaar, A., 2007, "Strategic crossroads - Where to Criminologists?" Acta Criminologica Journal, Vol 20 (1), pp. i-ii.

Sharp, J., 2000, “One Nation, Two Anthropologies? A Response to Coertze's 'Kommentaar op Geignoreerde Kritiek'”, South African Journal of Ethnology, Vol. 23 (1), pp. 30-33.

Spiegel, A.D., 1999, "Globalising Tendencies and Travelling Theories: Addressing Social Diversity in Housing and Literacy Policies in PostApartheid South Africa", African Anthropology Journal, Vol. VI, (1), pp. 55-71.

Vawda, S., 1998, "Power and Representation Inside Anthropology", African Anthropology Vol. V (1), pp. 7-32.

UCT Statement and Apology Regarding Professor A.B. Mafeje

http://www.uct.ac.za/downloads/uct.ac.za/about/management/ vcinstallation/Mafeje_apology.pdf 